Original Research Paper

\title{
The Investigation of Biological Nitrogen Fixation in Critical Dryland Pasture
}

\author{
${ }^{1}$ Syamsuddin Hasan, ${ }^{1}$ Budiman, ${ }^{1}$ Asmuddin Natsir, ${ }^{2}$ Sema and ${ }^{2}$ Purnama Isti Khaerani \\ ${ }^{1}$ Faculty of Animal Science, Hasanuddin University, Makassar, Indonesia \\ ${ }^{2}$ Bachelor Degree, Faculty of Animal Science, Hasanuddin University, Makassar, Indonesia
}

Article history

Received: 21-01-2019

Revised: 08-06-2019

Accepted: 19-07-2019

Corresponding Author:

Syamsuddin Hasan

Faculty of Animal Science,

Hasanuddin University,

Makassar, Indonesia

E-mail: syam_hasan@yahoo.com

\begin{abstract}
The aim of the study is to determine the production and growth of dwarf napier grass (Pennisetum purpureum cv.mott) integrated with siratro legumes (Macroptilium atropurpureum) contributing to the availability of preferred forage for ruminants on critical dryland. The study applied randomized block design consisted of 4 groups and 4 treatments; P0 consisted of $100 \%$ control Pennisetum purpureum cv.mott; P1 consisted of 70\% Pennisetum purpureum cv.mott and 30\% Macroptilium atropurpureum; P2 consisted of 50\% Pennisetum purpureum cv.mott and 50\% Macroptilium atropurpureum; P3 consisted of 30\% Pennisetum purpureum cv.mott and $70 \%$ Macroptilium atropurpureum. The results of this study showed that biological nitrogen fixation (BNF) significantly contributed to the plant's growth and forage production on critical dry pasture.
\end{abstract}

Keywords: Biological Nitrogen Fixation, Critical Dryland, Legume, Pasture

\section{Introduction}

Grazing management is a major system of livestock production in many countries (Snaydon, 1981; Bolan et al., 2004). Unlike natural rangeland pastures, the managed pastures are highly productive as increased pasture production lead to higher perhectare animal productivity. It is the major goal for the pastoral farmers. A significant portion of world milk and beef production is produced from managed pastures (Sere et al., 1995; Zhang et al., 2018). The effects of grazing intensity on the dynamics of plant composition is required for rational management of grasslands (Sternberg et al., 2015; Neilly et al., 2017). The key to grazing land is to provide forage for ruminant. However, the condition of critical dryland pasture becomes the constraint in the availability of forage in the tropical land. Therefore, generally farmers use inorganic fertilizers to increase the forage productivity in pasture. Under abiotic stress and inappropriate management, livestock grazing can lead to the loss of deeper-rooted perennial grasses and reduce ground cover and soil fertility (McKeon et al., 2009; Eldridge et al., 2011; Hera, 1996). Therefore, some farmers used chemical fertilizer. Chemical fertilizer plays an important role in increasing soil fertility and crop productivity (Roelcke et al., 2004; Dinesh et al., 2010). However, long term excessive use of chemical fertilizers will reduce soil organic matter content and consequent decline in the agricultural soil quality, increase in soil acidification and environment pollution (Guo et al., 2010; Hasan, et al., 2005; Tang et al., 2009).

The use of chemical fertilizers (inorganic) exceed the dose to get the forage productivity causes a decline in land fertility as germplasm media for plant growth, land arrangement that causes erosion and soil nutrient loss, soil organic matter loss, waterlogging, soil compaction and other forms of reduction in critical land or critical pasture (Hasan et al., 2015). Furthermore, nitrogen fertilizer requirements are often applied, thus inducing unintended environmental consequences such as nitrate leaching and nitrous oxide emission as well as ammonia leaching (Pandeya et al., 2017). The use of inorganic fertilizers on pasture land has to be reduced to produce organic feed for livestock. One solution to obtain a high forage production without using any chemical fertilizers is the integration between grass and legume through a process of biological nitrogen fixation (BNF). BNF is one of the most important sources of $\mathrm{N}$ in the agricultural system (Bertrand et al., 2011). Legumes are an integral part of organic cropping systems because they supply $\mathrm{N}$ through Biological NFixation (BNF). Legumes can support the intensification of organic crop production (Doltra et al., 2011) and pasture crop.

In grazed pastures, Nitrogen $(\mathrm{N})$ material is acquired from biological fixation of atmospheric $\mathrm{N}$, through the addition of manures and fertilizers. In non-legume-based 
pastures, such as grass pastures, the nitrogen is acquired from fertilizer. Although in legume-based pastures most of the $\mathrm{N}$ is derived from biological $\mathrm{N}$ fixation. Increased fertilizer $\mathrm{N}$ inputs along with a high intake of animal protein in developed countries (McCarl and Schneider, 2000; Mosier et al., 2001). Recently, the interest in mixed crops between legumes and grasses has highly increased due to their importance for sustainable and ecologically friendly agriculture (Luscher et al., 2014; Kusvuran et al., 2014). Legume-based grazing systems may be an option to improve the production, the forage quality and the profitability and sustainability of the system in tropical regions. It may have the ability to reduce environmental problems by increasing the Nitrogen Use Efficiency (NUE) avoiding a high transient surplus of soil mineral $\mathrm{N}$ (Totev and Chiurazzi, 2016; Resende et al., 2003). Legumes can also improve soil structure, enhance soil biological activity, and support crop nutrient supply (McCarl and Schneider, 2000). However, some legume species, soil and climatic conditions and the design of the rotation in an organic system can influence the amount of $\mathrm{N}$ contributed by legumes to the cash crops and the effect on crop yields (Mosier et al., 2001). BNF of legumes in the organic crop rotation can substitute much of the fertilizer $\mathrm{N}$ requirement of the subsequent crops (Askegaard, 2007). Increasing the productivity and quality of critical dryland pasture can be done by combining the grass and legume as the sources of BNF in which the results can have a significant influence on the production and quality of forage in pasture, but each legume species has different capability of nitrogen fixation (Mosier et al., 2001). The investigation on the BNF process in pasture is carried out to obtain a high forage production in critical dryland pasture. One type of superior grass and legume is dwarf napier grass (Pennisetum purpureum cv.mott) and siratro legume (Macroptilium atropurpureum). The grass and legume are integrated in some compositions in critical dryland in order to determine its production and growth. Therefore, it will give better contribution to the availability of forage for ruminants for future livestock farming systems with high environmental and economic performances (Peyraud and Lüscher, 2009).

\section{Research Methods}

This research was conducted from 2015 to 2016 on critical dryland pasture in Bulo Timoreng Village, Panca Rijang Sub-District, Sidenreng Rappang District, South Sulawesi Province located between $3^{\circ} 48^{\prime} 22$ "-351'54" South Latitude and 119 48'01" -119 53'32" East Longitude. The basic character of the soil and chemical composition were acquired in Tables 1 and 2 . The land is characterized by a tilt level of 0-15 degrees. The implementation of this research occurs during the long dry season, but it is supported by water pump and adequate groundwater supply (drilling wells $>20$ meters) so that the experimental plants are in normal condition (groundwater is available).

Analysis of materials and soil samples from the field was conducted at the Pasture Crop Laboratory, Chemical and Feed Nutrition and Integrated Laboratory of Animal Science Faculty of Hasanuddin University, Makassar. These laboratory results below acquired the average physical and chemical composition of field research soil.

Table 1: The physical composition of field research soil

\begin{tabular}{llrrr}
\hline & & Sample Spot & \\
Physical Composition & I & II & III & Averages $(\%)$ \\
\hline Texture) & I & 39 & 6 & 20.17 \\
Clay & 15.50 & 4 & 3 & 5.69 \\
Sand & 10.06 & 60 & 65 & 65.76 \\
\hline
\end{tabular}

Analysis of Chemical Feed Laboratory of Animal Science Faculty, Hasanuddin University, 2015

Table 2: The chemical composition of field research soil

\begin{tabular}{|c|c|c|c|c|c|}
\hline \multirow[b]{2}{*}{ Data } & \multirow{2}{*}{$\begin{array}{l}\text { Chemical } \\
\text { composition }\end{array}$} & \multicolumn{3}{|c|}{ Samples } & \multirow[b]{2}{*}{ Average $(\%)$} \\
\hline & & I & II & III & \\
\hline \multirow{5}{*}{ Organic Material } & $\mathrm{pH}$ & 6.60 & 6.30 & 6.50 & 6.47 \\
\hline & $\mathrm{KCl}(\%)$ & 5.20 & 5.40 & 5.60 & 5.40 \\
\hline & Carbon $(\%)$ & 0.85 & 0.15 & 0.60 & 0.53 \\
\hline & Nitrogen Total (\%) & 0.20 & 0.14 & 0.20 & 0.18 \\
\hline & Rasio C/N (\%) & 11.00 & 14.00 & 9.00 & 11.33 \\
\hline \multirow[t]{2}{*}{ Extract of $\mathrm{HCl} 25 \%$} & $\mathrm{P}_{2} \mathrm{O}_{5}(\mathrm{mg} / 100 \mathrm{gr})$ & 11.00 & 10.00 & 11.00 & 10.67 \\
\hline & $\mathrm{K}_{2} \mathrm{O}(\mathrm{mg} / 100 \mathrm{gr})$ & 23.00 & 22.00 & 24.00 & 23.00 \\
\hline \multirow[t]{2}{*}{ Olsen Bray-1 } & $\mathrm{P}_{2} \mathrm{O}_{5}(\mathrm{ppm})$ & 16.00 & 11.00 & 9.00 & 12.00 \\
\hline & $\mathrm{K}_{2} \mathrm{O}(\mathrm{ppm})$ & 112.00 & 118.00 & 116.00 & 115.33 \\
\hline
\end{tabular}

Analysis of Chemical Feed Laboratory, Animal Science Faculty, Hasanuddin University, 2015 


\section{Experimental Design}

The research arranged by Randomized Block Design (RBD) consisted of 4 groups of 4 treatments, that were P0 which consisted of Control 100\% dwarf napier grass ; P1 consisted of $70 \%$ dwarf napier grass and $30 \%$ siratro legume; P2 consisted of 50\% dwarf napier grass and 50\% siratro legume; $\mathrm{P} 3$ consisted of $30 \%$ dwarf napier grass and $70 \%$ siratro legume.

The parameter observed in this study is the influence of BNF in some components of forage growth, the combination of grass and legume.

The effects of cropping system (crop rotation, manure and cover crops) were analyzed separately for each crop type and location using cropping system.
The treatments as fixed effect were analyzed by using SPSS 16 software.

\section{Results}

Based on observations on the treatment of $\mathrm{P} 0, \mathrm{P} 1, \mathrm{P} 2$ and $\mathrm{P} 3$, the morphology of siratro legume nodule is presented in the Fig. 1.

The investigation of Biological Nitrogen Fixation (BNF) between dwarf napier grass and siratro legume contribute to an increase in the productivity of critical dryland pasture influenced by the ability of siratro legume to be symbiotic with nitrogen-fixing bacteria, it is presented in Table 3 to 6 .

\section{The Influence of BNF to Root Length, Number and Weight of Nodules}

Table 3: The influence of BNF (dwarf napier grass with siratro legume) against the root length, the number of nodules and the weight of nodules

\begin{tabular}{llll}
\hline Treatments & Root Length $(\mathrm{Cm})$ & $\begin{array}{l}\text { The Number } \\
\text { of Nodules }(\mathrm{gr})\end{array}$ & $\begin{array}{l}\text { The Weight } \\
\text { of Nodules }(\mathrm{gr})\end{array}$ \\
\hline P0 & $10.28^{\mathrm{b}} \pm 0.34$ & $0.00^{\mathrm{c}} \pm 0.00$ & $0.00^{\mathrm{c}} \pm 0.00$ \\
P1 & $11.34^{\mathrm{a}} \pm 0.33$ & $20.35^{\mathrm{b}} \pm 0.30$ & $0.21^{\mathrm{b}} \pm 0.00$ \\
P2 & $11.30^{\mathrm{a}} \pm 0.00$ & $20.45^{\mathrm{b}} \pm 0.00$ & $0.20^{\mathrm{b}} \pm 0.00$ \\
P3 & $11.27^{\mathrm{a}} \pm 0.00$ & $22.65^{\mathrm{a}} \pm 0.34$ & $0.26^{\mathrm{a}} \pm 0.00$ \\
\hline
\end{tabular}

Different superscript in the same column indicates significant difference $(\mathrm{P}<0.05)$

\section{The Influence of BNF to Plant Growth}

Table 4: The influence of BNF (dwarf napier grass and siratro legume) to plant height, leaf area, number of tillers and chlorophyll

\begin{tabular}{lllll}
\hline Treatments & Height $(\mathrm{Cm})$ & Leaf Area $\left(\mathrm{Cm}^{2}\right)$ & Number of tillers & Chlorophyll (Unit) \\
\hline P0 & $55.15^{\mathrm{c}} \pm 0.00$ & $74.54^{\mathrm{b}} \pm 0.00$ & $18.35^{\mathrm{a}} \pm 0.37$ & $24.45^{\mathrm{b}} \pm 0.33$ \\
P1 & $64.25^{\mathrm{a}} \pm 0.01$ & $125.49^{\mathrm{a}} \pm 0.01$ & $13.75^{\mathrm{b}} \pm 0.37$ & $33.62^{\mathrm{ab}} \pm 0.33$ \\
P2 & $61.49^{\mathrm{b}} \pm 0.00$ & $90.45^{\mathrm{b}} \pm 0.00$ & $10.45^{\mathrm{b}} \pm 0.33$ & $30.24^{\mathrm{ab}} \pm 0.29$ \\
P3 & $62.39^{\mathrm{b}} \pm 0.00$ & $89.76^{\mathrm{ab}} \pm 0.00$ & $7.35^{\mathrm{b}} 1.00$ & $34.57^{\mathrm{a}} \pm 0.32$ \\
\hline
\end{tabular}

Different superscript in the same column indicates significant difference $(\mathrm{P}<0.05)$

\section{Plants Production}

Table 5: Average weight in fresh, dried material and organic material on integrated dwarf napier grass with siratro legume

\begin{tabular}{lll}
\hline Treatments & Dry Matter $(\%)$ & Organic Matter $(\%)$ \\
\hline P0 & $25.81^{\mathrm{b}} \pm 0.00$ & $88.12^{\mathrm{b}} \pm 0.01$ \\
P1 & $32.49^{\mathrm{a}} \pm 0.00$ & $87.29^{\mathrm{c}} \pm 0.02$ \\
P2 & $29.79^{\mathrm{a}} \pm 0.01$ & $89.75^{\mathrm{a}} \pm 0.03$ \\
P3 & $22.92^{\mathrm{c}} \pm 0.00$ & $89.22^{\mathrm{a}} \pm 0.01$ \\
\hline
\end{tabular}

Different superscript in the same column indicates significant difference $(\mathrm{P}<0.05)$

\section{Protein Content and Crude Fiber}

Table 6: Average Protein and crude Fiber on integrated dwarf napier grass with siratro legume

\begin{tabular}{lll}
\hline Treatments & Protein $(\%)$ & Crude fiber (\%) \\
\hline P0 & $8,13^{\mathrm{a}} \pm 0.25$ & $31,61^{\mathrm{a}} \pm 0.33$ \\
P1 & $9,54^{\mathrm{b}} \pm 0.01$ & $32,87^{\mathrm{b}} \pm 0.33$ \\
P2 & $10,38^{\mathrm{c}} \pm 0.34$ & $35,71^{\mathrm{c}} \pm 0.37$ \\
P3 & $11,28^{\mathrm{d}} \pm 0.32$ & $36,35^{\mathrm{d}} \pm 0.34$ \\
\hline
\end{tabular}

Different superscript in the same column indicates significant difference $(\mathrm{P}<0.05)$ 


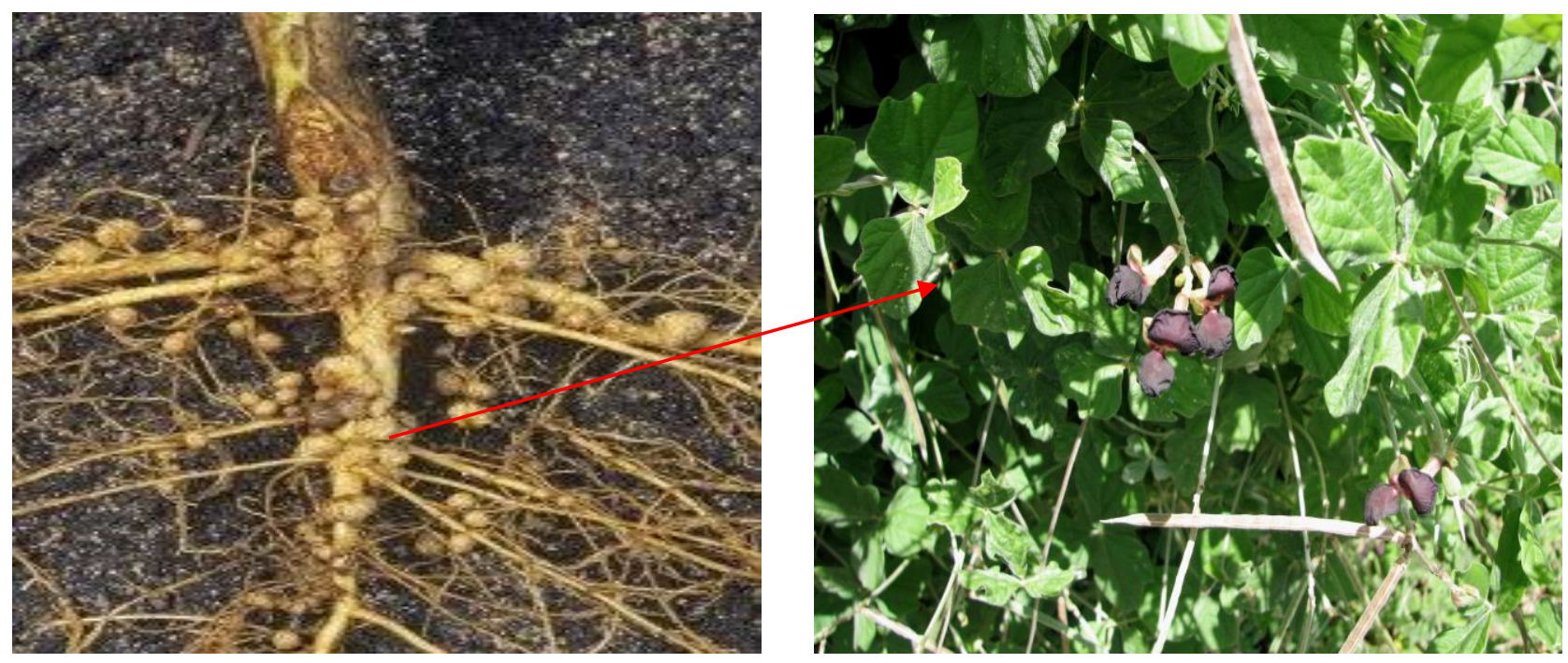

Fig. 1: Nodule on siratro legume roots

\section{Discussion}

\section{The Influence of BNF to Root Length, Number and Weight of Nodules}

Analysis of variance indicated that the investigation of BNF through the integration between dwarf napier grass and siratro legume significantly affected $(\mathrm{P}<0.05)$ the root length, the number and weight of nodules, as presented in Table 3. Among all treatments, P1 has a longer root compared to other treatments. The treatment with the highest number and the heaviest nodules was P3 compared to other treatments. It was caused by symbiosis between siratro legume and Rhizobium. The bacteria formed nodules on siratro legume (Fig. 1) and was able to bind nitrogen from the air. The contact between roots and soils, were sensitive to variations in soil conditions and microbial interactions (Wang et al., 2011; Brown et al., 2013; Hossain, 2015) the most important $\mathrm{N}$-fixing microbial agents are the symbiotic associations between crop and forage/fodder legumes and bacteria from the Rhizobia genus (Fustec et al., 2010; Liu et al., 2011). Rhizobia are a group of organisms which are nitrogen-fixing in symbiosis with legumes. In legume symbiosis with rhizobium, nitrogen fixation process is closely related to the host plant physiology. A type of environmental stress commonly faced by nodules of legumes and its rhizobium is drought, high soil temperature in tropical and subtropical regions, affecting BNF in legumes (Zahran, 1999). BNF is a natural process that allows microorganisms to convert atmospheric Nitrogen $\left(\mathrm{N}_{2}\right)$ into ammonia $\left(\mathrm{NH}_{3}\right)$ (Kahindi and Karanja, 2009). Nitrogen-fixing root nodules are organs that need to assimilate large amounts of energy source in the form of photosynthate products either for the formation of nodule primordium (Complainville et al., 2003) and to provide energy for the $\mathrm{N}$ fixation performed by the Rhizobium and assimilation of the produced ammonium and starch biosynthesis (Dilworth et al., 2008). Rhizobium-legume has the ability to develop a partnership for forming nodules as a repository for fixing nitrogen that can be used by the legume and energy resources for the bacterium (Predeepa and Ravindran, 2010).

\section{The Influence of BNF to Plant Growth}

Analysis of variance indicates that plant growth (height, leaf area, number of tillers and chlorophyll) in the investigation of BNF through the integration between dwarf napier grass and siratro legume has significantly affected $(\mathrm{P}<0,05)$ plant growth. As presented in Table 4, the treatment having a good plant height and leaf area is found in P1 treatment. The most number of tillers found in P0. On the analysis of chlorophyll, the high chlorophyll found in P3. It is due to the role of siratro legume in binding free nitrogen from the air and it can also help to enrich the soil. The formation of nodules is more able to increase further nitrogen fixation to form chlorophyll and enzymes (Apuzzo et al., 2014; Surtiningsih et al., 2009). The increase of chlorophyll and enzymes can improve photosynthesis which can increase the vegetative and generative growth of plant. If the available $\mathrm{N}$ element is enough for plants, the chlorophyll content in the leaves will be increased and the photosynthesis process will also be increased in more assimilation (Tania et al., 2012). 


\section{Plant Production}

Analysis of variance indicates that the investigation of BNF through the integration of BNF between grass and legume significantly affected $(\mathrm{P}<0.05)$ plant production as presented in Table 5. P1 that indicated the the highest production of dry matter. While the highest production of organic material was $\mathrm{P} 2$ and $\mathrm{P} 3$. It was due to the highest contribution of nitrogen. It can supply the nutrients that plants require in the critical dryland through BNF process. Hasan et al. (2015) stated that grass and legume in BNF process can increase forage production in critical dryland pasture. The utilization of nitrogen fixation process as biological fertilizer is environmentally friendly cultivation technology, sustainable and able to increase crop productivity (Novriani, 2011). It is in accordance with a study (Baddeley et al., 2014) reporting that planting mixture with legume on pasture is highly significant. Therefore, the improvement of pasture was affected by nitrogen fixation which can improve forage production. the intercropping (integration) of grass and legume is one method to increase forage production as well as to decrease inorganic nitrogen fertilizers. In the case of $\mathrm{N}_{2}-$ fixing crops, the potential $\mathrm{N}$ fixation is assumed to be proportional to the dry matter increase and is limited by a maximum daily $\mathrm{N}$ fixation rate. Fixation has an associated energetic cost, reducing the daily dry matter accumulation (Berntsen et al., 2004). The intercropping (integration) of grass and legume is one method to improve forage production as well as to reduce inorganic nitrogen fertilizers (Indra, 2006).

\section{Protein and Crude Fiber}

Analysis of variance indicates that the investigation of BNF through the integration of BNF between grass and legume significantly affected $(\mathrm{P}>0.01)$ protein and crude fiber as presented in Table 6. Treatment of P3 had the highest protein and crude fiber content compared to P0, P1 and P2 treatment. It was due to the effect of nutrient transfer from the legumes to the grass through the infection process to the grassroots by Rhizobium bacteria found in the grassroots. This was related to the research that showed nutrients transferring process from legume plants to grass plants through hyphae that infects grass root system (Herryawan, 2014).

\section{Conclusion}

The investigation of Biological nitrogen fixation (BNF) has a better result on the growth and productivity of pasture in critical dryland. The best result was in P1 and P3 treatment. The utilization of BNF to critical dry pasture was very appropriate to reduce environmental problems and to reduce the use of chemical fertilizers (inorganic).

\section{Acknowledgement}

The research team expressed our gratitude and appreciation for funding support of this research to the Ministry of Research, Technology and Higher Education and the Institute of Research and Community Service, Hasanuddin University.

\section{Funding Information}

This Manuscript was funded by Ministry of Research, Technology and Higher Education of Indonesia through Research and Extention Institute of Hasanuddin University.

\section{Author's Contributions}

Syamsuddin Hasan: Designing the experiments and wrote the manuscript.

Budiman: Performing the experiment and analyzed the data.

Asmuddin Natsir: Performing the experiment and writing the manuscript.

Sema: Performing the experiment and analyzing the data.

Purnama Isti Khaerani: Wroting the manuscript and analyzing the data.

\section{Ethics}

This manuscript has not been published or presented elsewhere in part or in entirely and is not under consideration by another journal. All the authors have approved the manuscript and agree with submission to the esteemed journal. There are no conflicts of interest to be declared.

\section{References}

Apuzzo, D.E., T.V. Valkov, A. Parlati, S. Omrane and A. Barbulova, 2014. Overexpression in Lotus japonicus affects nodule activity in permissive low nitrogen conditions and increases nodule numbers in high nitrogen treated plants. Mol. Plant-Microbes Interact, 28: 432-442.

Askegaard, M. and J. Eriksen, 2007. Growth of legume and nonlegume catch crops and residual-N effects in spring barley on coarse sand. J. Plant Nutr. Soil. Sci., 170: 773-780.

Baddeley, J.A., S. Jones, C.A. Topp, C.F.E. Watson and J. Helming, 2014. Biological Nitrogen Fixation (BNF) by legume crops in Europe. Legume Futures Report 1.5.

Berntsen, J., H. Hauggard-Nielsen, J.E. Olesen and B.M. Petersen, 2004. Modelling dry matter production and resource use in intercrops of pea and barley. Field Crops Res., 88: 69-83. 
Bertrand, H., T. Tétu, L.J. Peter and F. Dubois. 2011. Improving nitrogen use Efficiency in Crops for Sustainable Agriculture. Sustainability, 3: 1452-1485.

Bolan, N.S., S. Saggar, J. Luo, R. Bhandra and J. Singh, 2004. Gaseous emissions of nitrogen from grazed pastures: processes, measurements and modelling, environmental implications and mitigation. Adv. Agronomy, 84: 39-120.

Brown, L.K., T.S. George, G.E. Barrett, S.F. Hubbard and P. J. White, 2013. Interactions between root hair length and arbuscular mycorrhizal colonisation in phosphorus deficient barley (Hordeum vulgare). Plant Soil, 372: 195-205.

Complainville, A. L. Brocard, R.E. Dax, N. Sever and N. Sauer, 2003. Nodule initiation involves the creation of a new symplasmic field in specific root cells of medicago species. Plant Cell, 120: 2778-2791.

Dilworth, M.J., E.K. James, J.I. Sprent and C.P. Vance, 2008. Carbon and Nitrogen Metabolism in Legume Nodules. In: Nitrogen-Fixing Leguminous Symbioses, Berlin (Ed). Springer, Germany, pp: 293-320.

Dinesh, R., V. Srinivasan, S. Hamza and A. Manjusha, 2010. Shortterm incorporation of organic manures and biofertilizers influences biochemical and microbial characteristics of soils under an annual crop (Turmeric (Curcuma longa L.). Bio. Technol., 101: 4697-4702.

Doltra, J., M. Laegdsm and J.E. Olesen, 2011. Cereal yield and quality as affected by nitrogen availability in organic and conventional arable crop rotations: A combined modeling and experimental approach. Eur. J. Agron, 34: 83-95.

Eldridge, D.J., J. Val and A.I. James, 2011. Abiotic effects predominate under prolonged livestockinduced disturbance: Livestock-induced disturbance in woodlands. Australian Ecol., 36: 367-377.

Fustec, J., F. Lesuffleur, S. Mahieu and J.B. Cliquet, 2010. Nitrogen rhizodeposition of legumes. Rev. Agron. Sustain. Dev., 30: 57-66.

Guo, J.H., X.J. Liu, Y. Zhang, J.L. Shen and W.X. Han, 2010. Significant acidification in major Chinese croplands. J. Sci., 327: 1008-1010.

Hasan, S., Budiman, R. Ilham and S. Sudarsono, 2015. The productivity increase of critical pasture through the intercropping of grass and legume as Biological Nitrogen Fixation source in Sidenreng Rappang. Proc. J.

Hasan, S., Y. Masuda, M. Shimojo and A.Natsir. 2005. Changes in the chemical and physical soil condition of a marginal land planted with three strata forage system under three years of grazing. J. Fac. Agr. Kyushu Uni., 50: 129-133.

Hera, C., 1996. The role of inorganic fertilizers and their management practices. Fertilizer Res., 43: 63-81.
Herryawan, K. M. 2014. The mechanism of transfer of nutrients from legumes to inoculated grass FMA. J. Pastura, 4: 20-25.

Hossain, M.S., 2015. Soybean root hair, a single cell model to study plant-microbe interactions, abiotic stress and epigenetic regulation. Proceedings of the 23rd Conference Plant and Animal Genome, (PAG' 15), San Diego, CA.

Indra, A., 2006. Forage crop production in different type and planted line of legume by intercropping system with elephant grass (Pennisetum purpureum). Agriculture Facult, Sriwaya University Proceeding.

Kahindi, J.H.P. and N.K. Karanja, 2009. Biotechnology and Genetic Engineering Technology Assessment: Essentials of Biological Nitrogen Fixation Technology. In: Encyclopedia of Life Support Systems (EOLSS) -Biotechnology: Knowledge in Depth, Horst, W.D. (Ed).

Kusvuran, A.Y.R. and T. Saglamtimur, 2014. Determining the biomass production capacities of certain forage grasses and legumes and their mixtures under mediterranean regional conditions. Acta Adv. Agric. Sci., 2: 13-24.

Liu, Y.Y., L.H. Wu, J.A. Baddeley and C.A. Watson, 2011. Models of biological nitrogen fixation of legumes. A review. Agron. Sustain. Develop., 31: 155-172.

Luscher, A., J.F. Mueller-Harvey, R.M. Soussana and J.L. Peyraud, 2014. Potential of legume-based grassland-livestock systems in Europe: A review. Grass Forage Sci., 69: 06-228.

McCarl, B.A. and U.A. Schneider, 2000. US agriculture's role in a greenhouse gas emission mitigation world: An economic perspective. Rev. Agric. Econ., 22: 134-159.

McKeon, G.M., G.S. Stone, J.I. Syktus, J.O. Carter and N.R. Flood, 2009. Climate change impacts on northern Australian rangeland livestock carrying capacity: A review of issues. Rangeland J., 31: 1-29.

Mosier, A., M.A. Bleken, P. Chaiwanakupt, E.C. Ellis and J.R. Freney, 2001. Policy implications of humanaccelerated nitrogen cycling. Biogeochemistry, 52: 281-320.

Neilly, H., P.O. Reagain, J. Vanderwal and L. Schwarzkopf, 2017. Profitable and sustainable cattle grazing strategies support reptiles in tropical savanna rangeland.

Novriani, 2011. The role of Rhizobium in increasing the nitrogen availability in soybean. Agronobi Sci., 3: 1-11.

Pandeya, A., F. Lib, M. Askegaardc and J.E. Olesena, 2017. Biological nitrogen fixation in three long-term organic and conventional arable crop rotation experiments in Denmark. Euro. J. Agronomy, 90: 87-95. 
Peyraud, J.L., A.L. Gall and A. Lüscher, 2009. Potential food production from forage legumebased-systems in Europe: An overview. Irish J. Agr. Food Res. 48: 115-135.

Predeepa, R.J. and D.A. Ravindran, 2010. Nodule formation, distribution and symbiotic efficacy of Vigna unguiculata $\mathrm{L}$. under different soil salinity regimes Emir. J. Food Agr., 22: 275-284.

Resende, A.S., R.P. Xavier, D.M. Quesada, S. Urquiaga and B.J.R. Alves, 2003. Use of green manures in increase inputs of biological nitrogen fixation to sugar cane. Biol. Fertility Soil., 37: 215-220.

Roelcke, M., Y. Han, K.H. Schleef, J.G. Zhu and G. Liu, 2004. Recent trends and recommendations for nitrogen fertilization in intensive agriculture in eastern China. Pedosphere, 14: 449-460.

Sere, C., H. Stenifeld and J. Groenewold, 1995. World Livestock Production Systems: Current Status, Issues and Trends. 1st Edn., Food and Agriculture Organisation of the United Nations, Rome, Italy, ISBN-10: 9251038120 , pp: 82.

Snaydon, R.W., 1981. The Ecology of Grazed Pastures. In: Grazing Animals, Morley, F.H.W. (Ed.), Elsevier, Amsterdam.

Sternberg, M., C. Golodets, M. Gutman, A. Perevolotsky and E.D. Ungar, 2015. Testing the limits of resistance: a 19-year study of Mediterranean grassland response to grazing regimes. Global Change Biol., 21: 1939-1950.
Surtiningsih, T., S. Farida and T. Nurhayati, 2009. Biofertilization of rhizobium bacteria in soybean plants (Glycine max (L) Merr.). Berk. Penel. Hayati, 15: 31-35.

Tang, X.J., G. Xi, C. Xin-Ping, Z. Shao-Lin and Z. LiJuan, 2009. Reducing environmental risk by improving $\mathrm{N}$ management in intensive Chinese agricultural systems. Agr. Sci., 106: 3041-3046

Tania, N., Astina and S. Budi, 2012. Effect of biofertilizer on growth and yield of semi-maize on red-yellow podzolic soil. J. Sains Mahasiswa Pertanian, 1: 10-15.

Totev, V.V. and M. Chiurazzi, 2016. An in vitro procedure for phenotypic screening of growth parameters and symbiotic performances in lotus corniculatus cultivars maintained in different nutritional conditions. Plants, 5: 40-40.

Wang X., Q. Pan, F. Chen, X. Yan and H. Liao, 2011. Effects of co-inoculation with arbuscular mycorrhizal fungi and rhizobia on soybean growth as related to root architecture and availability of $\mathrm{N}$ and P. Mycorrhiza, 21: 173-181.

Zahran, H.H., 1999. Rhizobium-legume symbiosis and nitrogen fixation under severe conditions and in an arid climate. Micribiol. Mol. Biol. Rev., 63: 968-989

Zhang C., Q. Dong, H. Chu, J. Shi and S. Li, 2018. Grassland community composition response to grazing intensity under different grazing regimes. Rangeland Ecol. Manage., 71: 196-204. 